\title{
Potential pathway for recycling of the paper mill sludge compost for brick
}

\section{making}

Gaurav Goel ${ }^{\mathrm{a}, b *}$, Milica Vidak Vasićc, Nirmal Kumar Katiyar ${ }^{\mathrm{a}}$, Kirthika S. K. ${ }^{\mathrm{a}}$, Milada Pezo ${ }^{\mathrm{d}}$, P.

Dinakar

${ }^{a}$ School of Engineering, London South Bank University, 103 Borough Road, London, SE10 AA, UK

${ }^{b}$ School of Aerospace, Transport and Manufacturing, Cranfield University, Bedford, MK43 OAL, UK

${ }^{c}$ Institute for Testing of Materials IMS, Bulevar vojvode Mišića 43, 11000 Belgrade, Serbia

${ }^{d}$ Department of Thermal Engineering and Energy, "VINČA" Institute of Nuclear Sciences - National Institute of the Republic of Serbia, University of Belgrade, 11001 Belgrade, Serbia

${ }^{e}$ Department of Civil Engineering, Indian Institute of Technology Bhubaneswar (IITBBS), Khordha, Odisha, India - 752050

*Corresponding author Email: goelg@1sbu.ac.uk

\section{Abstract}

This study's focus was to develop a potential pathway for recycling of the paper mill sludge compost (PMSC) in brick making. Composting reduces the paper mill sludge (PMS) moisture content considerably and shredding becomes easier. The addition of PMSC leads to an increase of porosities in bricks and makes them lighter, besides delivering energy to the firing process from burning organics. Lighter construction materials help minimize construction outlay by reducing labour and transportation costs and lesser expense on foundation construction. The variability in the experimental data and the brick properties were investigated for two types of soils, typical in the brick industry of India (alluvial and laterite soil), blended with PMSC in five mix ratios $(0 \%, 5 \%, 10 \%, 15 \%$ and $20 \%)$. The samples of oven-dried bricks were fired at two different temperatures $\left(850\right.$ and $\left.900{ }^{\circ} \mathrm{C}\right)$ in an electrically operated muffle furnace representing typical conditions of a brick kiln. Various properties of bricks were analyzed which included linear shrinkage, bulk density, water absorption and compressive strength. Conclusions were drawn based on these properties. It was found that the addition of PMSC to 
the alluvial and laterite soil by up to $10 \%$ weight yield mechanical properties of fired bricks compliant with the relevant Indian and ASTM codes. Toxicity characteristic leaching procedure (TCLP) tests showed that PMSC incorporated fired bricks are safe to use in regular applications as non-load-bearing and infill walls. This study is timely in light of the European Green Deal putting focus on circular economy. Besides, it fulfills the objective of UN sustainable development goals (SDG).

Keywords: Paper mill sludge compost; Fired bricks; Recycling; Sustainability; Wasteto-brick; Laterite soil; Alluvial soil

41 List of abbreviations:

2 AAS: Atomic absorption spectrometer

DSC: Differential scanning calorimetry

ETE: Estimated total emissions

HHV: Higher heating value

LOI: Loss on ignition

PMS: Paper mill sludge

PMSC: Paper mill sludge compost

SEM - Scanning electron microscope

TCLP: Toxicity characteristic leaching procedure

TGA: Thermogravimetric analysis

2 XRD: X-ray diffraction

3 XRF: X-ray fluorescence 


\section{Introduction}

Growing urbanization and sky rise construction of modern buildings have led to the increasing demand for already scarce construction raw materials. Clay obtained from opened quarries is an ideal example that has long been used for brick making. On the other hand, urbanization has also led to the problem of waste management both from domestic and industrial sites. Consequently, there is an arduous need for a collective and joint campaign to develop solutions for waste management as well as to save the precious raw materials which once undergoing an irreversible thermodynamic process will take far too long to recycle. As an example, the construction industry is one area where waste materials are easy to utilize without creating any adverse environmental effect $[1,2]$.

Worldwide, paper manufacturing is responsible for a significant amount of wastes [3, 4]. This is inevitable because the paper is at the heart of everyone's life whether it includes flicking through a newspaper to begin the day, notebooks required to teach kids in school or at Universities, documentation in offices or courts, and in more recent time also as serving plates and as packing bags as the paper is far more recyclable over plastic bags. Therefore, researchers have been looking into innovative ways for managing paper mill sludge (PMS). PMS is recycled as a source of energy through incineration and anaerobic digestion [5-8]. Ash is produced in incineration and anaerobic digestion produces digested slurry. One way of using this PMS ash is in the making of concrete slurry, where part of cement is substituted by ash additive [9] to achieve better bonding strength of the slurry mix.

Other researchers suggest producing wood-paper sludge boards by substituting a certain amount of wood chips with PMS $[10,11]$. However, substitution makes the board weaker by reducing strength [11]. PMS can also be utilized in fired brick manufacturing [2, 12-14]. However, inventory control of PMS poses significant challenges. To overcome this problem 
one way is to convert PMS waste into compost which can be easily stored without requiring as much volume of storage required by raw PMS $[15,16]$.

Unlike other high-value composts, the agricultural use of PMSC is problematic. Numerous soil contaminants may be applied in the agricultural fields. German Environmental Protection Agency does not allow agricultural use as the ecological risk potential of deinking sludge is not adequately known. A recent study [15] has shown that bioavailable heavy metals may be present in PMSC. Leaching of heavy metals poses a health hazard and therefore, the use of PMSC in agriculture cannot be recommended. Compost has been used as a substitute for soil cap on landfills [17, 18], rehabilitation of mine sites and tailings [19], and as fuel briquettes [20]. An alternative substitute being proposed is to use the PMSC in brick making.

China, India, Brazil, Spain and Italy are the biggest consumers of fired bricks in that order [21]. Out of all the fired bricks made worldwide, $80 \%$ of bricks are consumed by China and India alone. As per one estimate, a brick kiln caters to the requirement of 10,000 people in India [22]. Brick making comes at the expense of consuming precious fertile soil and a considerable incentive is hidden in saving this soil by developing partial substitutes to it such as dredged sediments [23]. To reduce the consumption of soil, researchers have suggested blending of various solid waste materials in the making of bricks. Glass waste [24, 25], agricultural waste [26, 27], biosolids [28], waste marble sludge [29], degraded municipal solid waste [1], PMS [2] are all been used to create waste incorporated bricks. Since PMS contains a large amount of moisture along with fibrous content, it is not so relevant for direct industrial use. As argued above, composting reduces the PMS moisture content considerably and shredding becomes easier besides providing inventory control. Besides, the fibers strengthen the green products, which is important in transportation and bearing the load in a kiln when firing begins. Hence, using PMSC over PMS became the key motivation for this work and is being explored in this paper as an additive for brick making. The novelty of the work is to make use of PMSC in brick 
making for the first time. This body of work is the first to report on utilizing PMSC in brick fabrication and to establish the structure-property relationships.

\section{Materials and methods}

\subsection{Materials}

This laboratory-scale work made use of paper mill sludge (PMS), cow dung and sawdust (mixed in 5:1:1 ratio). The mixture was composted using a rotary drum composter (Capacity $500 \mathrm{~L}$ ), to accelerate the process of composting and the process was accomplished within 15 days [30]. PMS was collected from Nagaon Paper Mill, state of Assam, India. Two types of soil (i) laterite soil; (ii) alluvial soil were gathered from the Guwahati region, state of Assam, India. The motive to select these particular two soil types stems from the Indian standards [31, $32]$ and other research works $[1,2,33]$ so that the results obtained can be linked retrospectively. These soils are widely used in India for centuries in the brick-making and they were obtained from Guwahati region as they are easily available and abundant. The soil samples were thoroughly oven-dried (median size of $150 \mu \mathrm{m}$ ) before the brick making process.

\subsection{Methods for characterization of soils and PMSC}

As one of the aims of this paper is to establish the structure-property relationship, it became a prerequisite to characterize all the raw materials used so those insights can be gained into linking the results with the properties of the raw materials utilized. Accordingly, soils and PMSC were analyzed to understand their mineralogical, chemical, thermal and plastic index properties using several state-of-the-art instruments. Elemental analyses of total nitrogen, 
carbon, hydrogen and sulfur were executed to get some idea of the anatomy of the organic matter (Euro Vector, EuroEA3000).

The phase composition of raw materials was identified using X-ray diffraction and TGA. The XRD apparatus used was a Rigaku, TTRAX III power X-ray Diffractometer equipped with a monochromator using $\mathrm{CuK}_{\alpha}$ radiation $(\lambda=1.5406 \AA)$. The scan rate was kept $4 \% \mathrm{~min}$. The analysis was done using the ICDD database. TGA was carried out on crushed samples heated to $1000{ }^{\circ} \mathrm{C}$ at a constant rate of $10{ }^{\circ} \mathrm{C} / \mathrm{min}$ in a static nitrogen atmosphere. The calorimeter was used for measuring the heating values (Parr 1341, 6775 digital thermometer). AAS was used for heavy metals determination (Thermo scientific, iCE 3000). A standard protocol was followed for sample digestion [34]. Atterberg limits and specific gravity tests were conducted as prescribed by BIS: $2720-1985$ (revised in 2015). The surface of the samples was analyzed using a scanning electron microscope (JEOL JSM-6610 LV)Before analysis, the samples were covered with a layer of gold for better reflection, using a coating spray device. Finally, XRF (PANalytical, AXIOS) was used to examine the chemistry of the dried material.

\subsection{Procedure for brick making and characterization}

PMSC was combined independently in both types of soils in different magnitudes as shown in Fig. 1. Homogenization of the mixture was achieved using mechanical stirring. The minimum quantity of water (20-22\%) based on the clay workability chart was added to achieve the state of plasticity for the mixes. To avoid cracking during drying, moulded brick samples were (i) air-dried under ambient conditions for $24 \mathrm{~h}$ and, (ii) subsequently oven-dried at $105 \pm 5$ ${ }^{\circ} \mathrm{C}$ further $24 \mathrm{~h}$. Being a testbed study, the brick specimens made were of dimension $61 \mathrm{~mm} \times$ $29 \mathrm{~mm} \times 19 \mathrm{~mm}$ using hand moulding. This size was downscaled from the existing dimension of $230 \mathrm{~mm} \times 110 \mathrm{~mm} \times 70 \mathrm{~mm}$ [35]. Henceforth, the oven-dried bricks are referred to as unfired 
bricks. Reference brick samples were made purely with the two types of soil samples without any PMSC for benchmarking the results.

The bricks were distinguished by marking them as L (laterite soil) and A (alluvial soil). Statistical variation of the results was studied by preparing and testing six samples for each series. The compacted samples were sintered at different firing temperatures (i.e. 850 and 900 ${ }^{\circ} \mathrm{C}$ ) mimicking typical kiln conditions. The rate of heating was $2{ }^{\circ} \mathrm{C} / \mathrm{min}$ and bricks were hold for an hour at peak firing temperature.

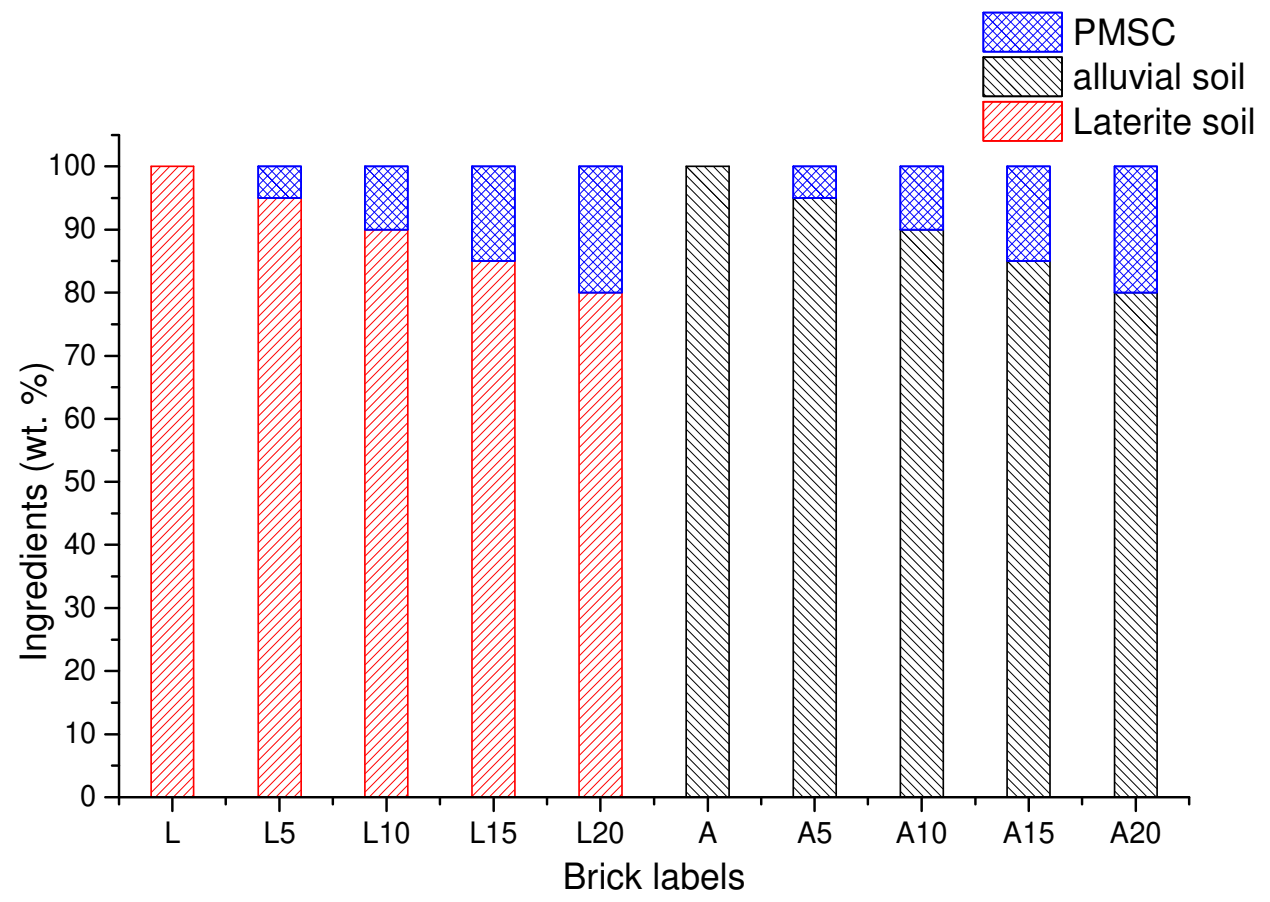

Fig. 1. Compositions of brick specimens.

To understand the carbon footprint of these fired bricks, gaseous emissions were measured using the strategy mentioned in our earlier work [33]. The chemo-mechanical identification procedure enacted in this exercise is similar to the preceding works and is not repeated here for brevity [1, 2, 33]. Linear shrinkage, loss on ignition, water absorption ( $5 \mathrm{~h}$ boiling test), apparent porosity, and bulk density were deduced following relevant ASTM standards (ASTM C326, ASTM C373, and ASTM C67). The compressive strength and modulus of elasticity of 
fired samples were measured using a universal testing machine (UTM, BISS, Median-250) as described by different standards [36-38].

\section{Results and discussion}

The systematic measurements of the important parameters during the process of brick making and the quality of fired products, following the procedure in agreement with various international standards, are presented in this section.

\subsection{Determination of chemical composition}

Chemical composition results (Fig. 2) evince (i) laterite soil and, (ii) alluvial soil are composed of primarily silica and alumina with some amount of flux agents $\left(\mathrm{K}_{2} \mathrm{O}, \mathrm{Fe}_{2} \mathrm{O}_{3}, \mathrm{CaO}\right.$, $\mathrm{MgO}$ and $\mathrm{TiO}_{2}$ ). Laterite soil exhibited a significant quantity of $\mathrm{Fe}_{2} \mathrm{O}_{3}(10.49 \%)$ which is also reported by another independent study [39]. The loss on ignition (LOI) values for both types of soils were very low $(<10 \%)$. It was established that both soils are kaolinitic, non-calcareous, and low refractory [33].

PMSC is primarily composed of carbon as disclosed by elemental analysis (hydrogen $(2.48 \%)$, carbon $(25.16 \%)$, and nitrogen $(3.11 \%))$. PMSC samples were found free from sulfur. The calorific value of PMSC was $2232 \mathrm{kcal} / \mathrm{kg}$. Similar to soils used in this work, PMSC contained mainly silica and alumina. Heavy metal contents for both soils and PMSC are given in Fig. 3. 


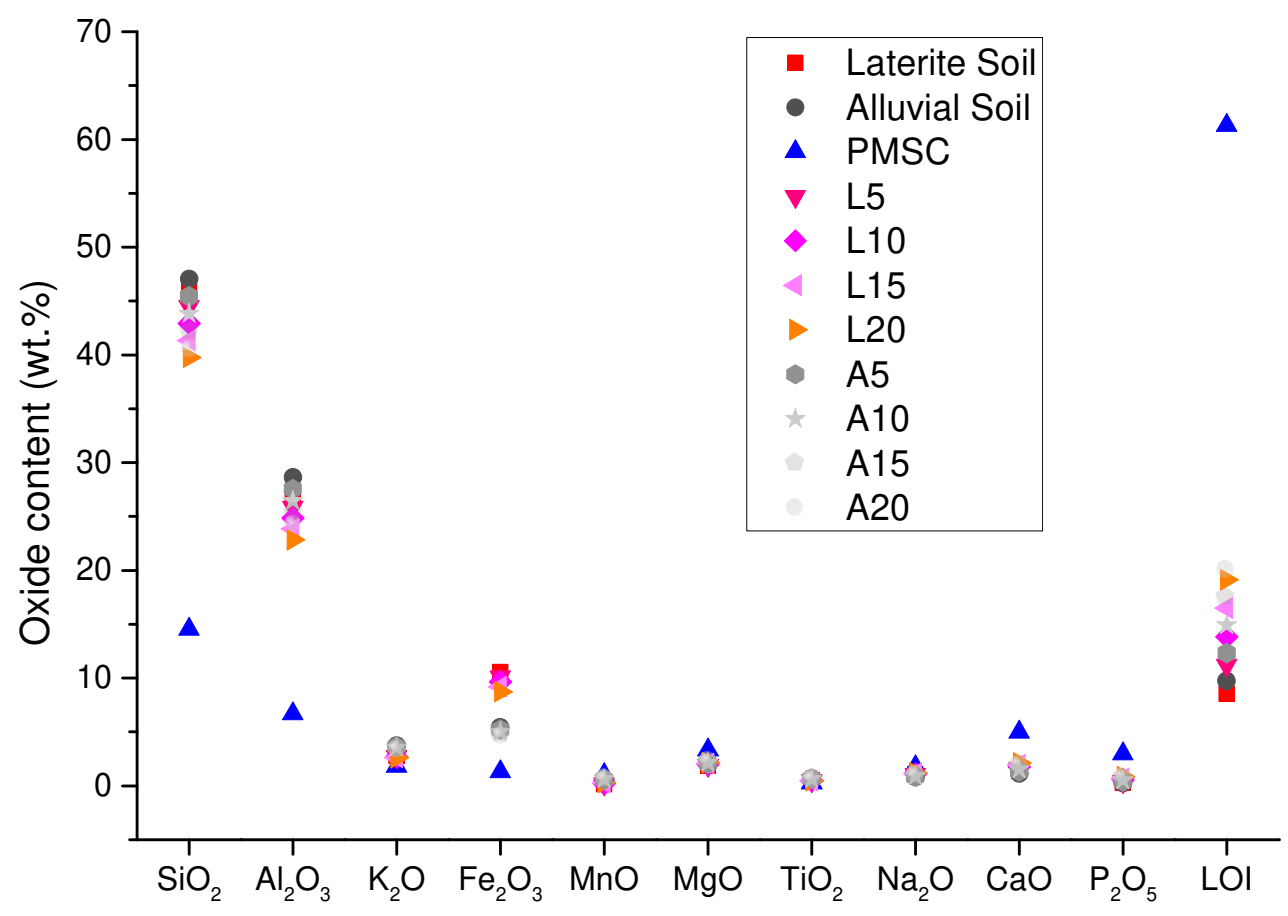

194

195 Fig. 2. Chemical analysis of oven-dried soils, PMSC, and brick compositions.

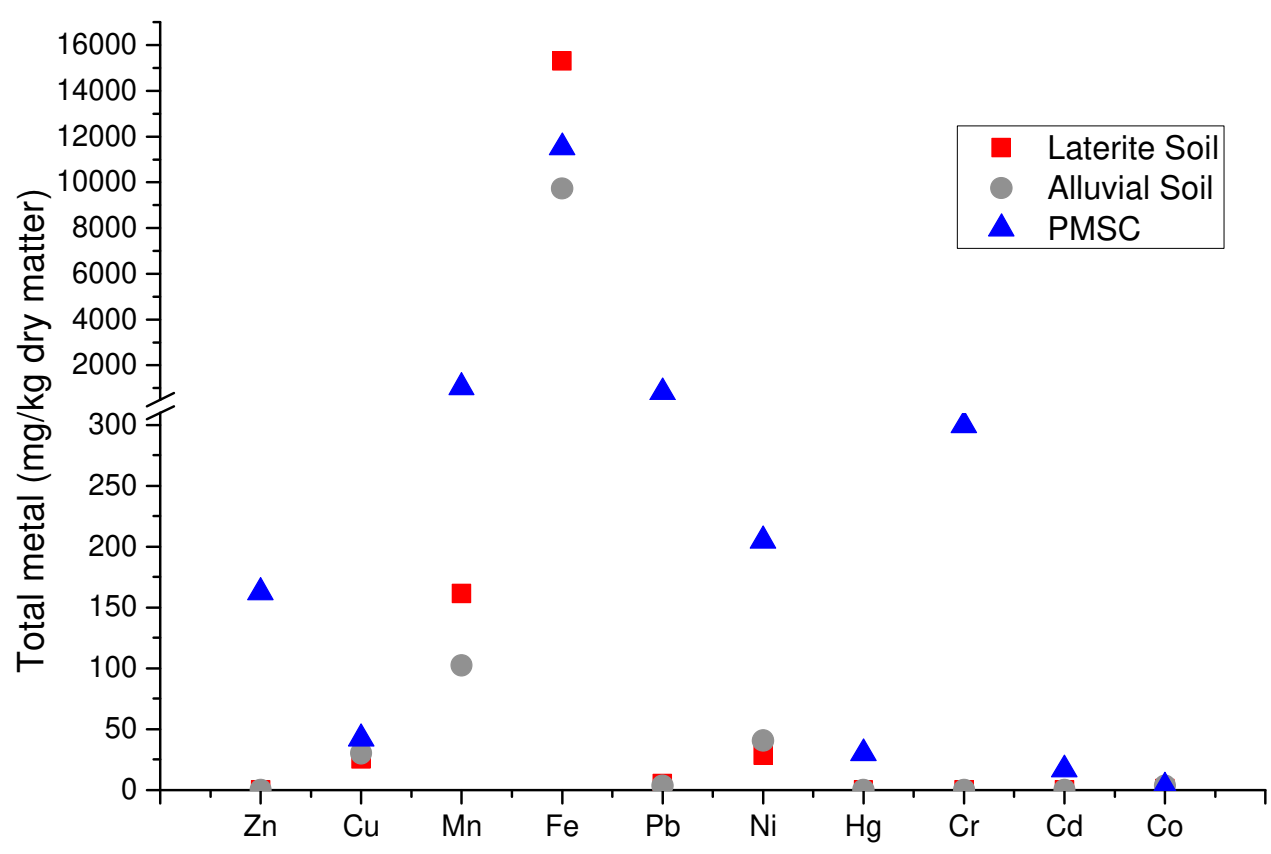

Fig. 3. Trace metal concentration in both soils and PMSC after oven drying.

Phase composition results also established that both soils were rich in silica $\left(\mathrm{SiO}_{2}\right)$. PMSC 
anorthite $\left(\mathrm{CaAl}_{2} \mathrm{Si}_{2} \mathrm{O}_{8}\right)$, aluminum orthophosphate $\left(\mathrm{AlPO}_{4}\right)$, magnesioferrite $\left(\mathrm{MgFe}_{2} \mathrm{O}_{4}\right)$, kutnohorite $\left(\mathrm{CaMn}\left(\mathrm{CO}_{3}\right)_{2}\right)$, quartz $\left(\mathrm{SiO}_{2}\right)$ and dolomite $\left(\mathrm{MgCO}_{3} \cdot \mathrm{CaCO}_{3}\right)$. This depicts changes as PMS contained primarily dolomite, carnegieite, microcline, and periclase [2]. Except microcline other phases were transformed.

Thermal analysis of PMSC was done and rapid mass loss $(\sim 50 \%)$ up to $400{ }^{\circ} \mathrm{C}$, possibly due to the volatilization of hemicellulose and cellulose was observed. Beyond $400{ }^{\circ} \mathrm{C}$, mass loss was minor $(\sim 10 \%)$. The loss on ignition (LOI) values for PMSC was $40 \%$.

\subsection{Characteristics of the bricks}

The physical characterization of the developed bricks such as shrinkage, porosity, loss on ignition, dry weight, and bulk density was evaluated on the specimens. The results of the mean dry weight of unfired bricks are presented in Table 1. From the table, it is apparent that the increase in the replacement percentage has a significant influence on the dry weight of the bricks. As the replacement percentage of soils increased from 5-20\% the corresponding dry weight also decreased by $15-17 \%$ making the bricks lighter. This was observed both in the cases of laterite and alluvial soils used. However, the bricks were lighter when PMSC was used.

From the results obtained (Table 1), it can also be seen that the unfired bricks containing laterite soil showed a slightly better packing of particles while moulding, which resulted in higher bulk densities. The reasons for this effect are in the particle size distribution of the used soils presented earlier [2]. Particle size distribution, i.e. texture, plays a significant role in brick raw materials in terms of their behavior in the technological process. A Winkler diagram showing the particle size distribution of both soils has been provided in Fig. 4 [40]. Researchers $[41,42]$ found that it is necessary to have an adequate particle size distribution to prevent the occurrence of errors in the technological process during the production of bricks. Of course, 
there is a connection between the particle dispersion and the mineralogical composition of the brick clays. An increase in the dispersion of brick clays and the content of fine particles causes greater shrinkage, plasticity, sensitivity to drying, bulk density and compressive strength [43]. The behavior is intensified during the firing process.

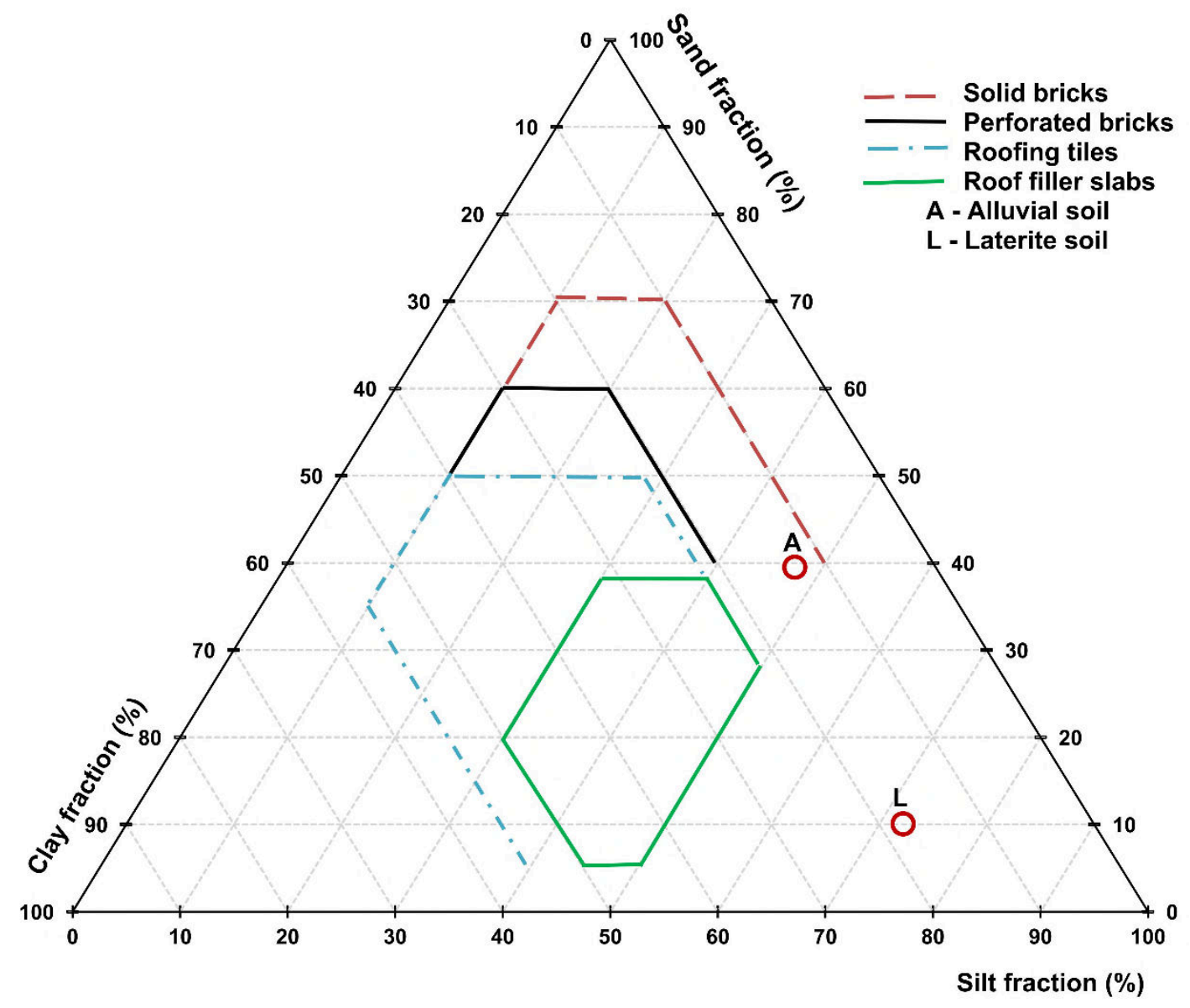

Fig. 4. Winkler diagram showing particle size distribution of soils [44].

While performing various procedures, brick specimens were recognized to be comprehensively fired and free from any defects (i.e. bloating, black coring, cracks, and efflorescence). The appearance of bricks developed from one type of soil was dark -red whereas the other type of soil gave a brick-red colour. Ferric oxide in laterite soil (9.49\%) and alluvial soil $(6.38 \%)$ is mainly responsible for the colour of the bricks since the content of carbonates was similar in both raw materials (Fig. 5). Both soils belonged to the well-sintering group since they contained more than $5 \%$ of $\mathrm{Fe}_{2} \mathrm{O}_{3}[45]$. 
Table 1

The mean oven-dried weights and bulk densities of unfired bricks.

\begin{tabular}{lll}
\hline Brick labels & $\begin{array}{l}\text { Mean oven- } \\
\text { dried weight }(\mathbf{g})\end{array}$ & $\begin{array}{l}\text { Bulk density of } \\
\text { unfired bricks } \\
\left(\mathbf{g} / \mathbf{c m}^{\mathbf{3}}\right)\end{array}$ \\
\hline L & $52.69 \pm 0.35$ & $1.57 \pm 0.12$ \\
L 5 & $46.26 \pm 0.29$ & $1.38 \pm 0.08$ \\
L 10 & $44.59 \pm 0.41$ & $1.33 \pm 0.09$ \\
L 15 & $43.52 \pm 0.43$ & $1.29 \pm 0.13$ \\
L 20 & $41.55 \pm 0.37$ & $1.24 \pm 0.07$ \\
A & $49.47 \pm 0.51$ & $1.47 \pm 0.14$ \\
A 5 & $44.73 \pm 0.49$ & $1.33 \pm 0.10$ \\
A 10 & $42.87 \pm 0.46$ & $1.28 \pm 0.11$ \\
A 15 & $41.58 \pm 0.55$ & $1.24 \pm 0.11$ \\
A 20 & $39.45 \pm 0.58$ & $1.17 \pm 0.13$ \\
\hline
\end{tabular}

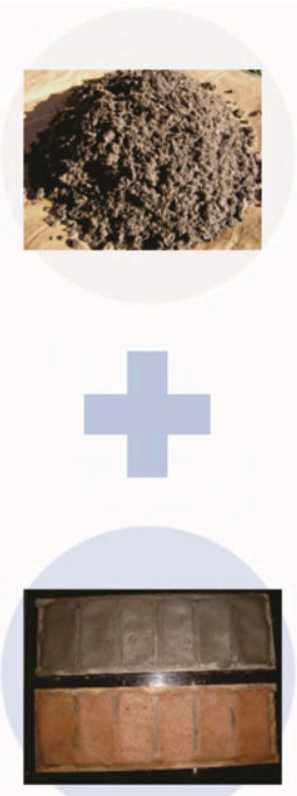

PMSC

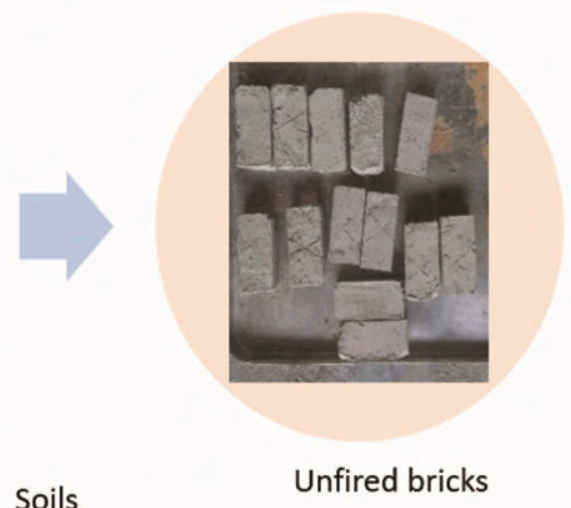
(a) Alluvial (Top)
(b) Laterite (Bottom)

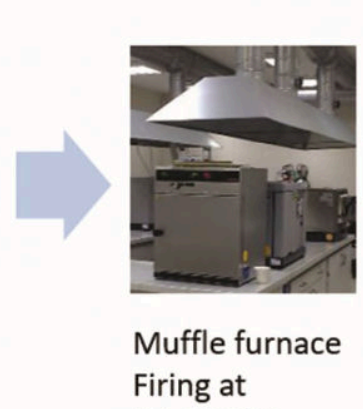

(a) $850^{\circ} \mathrm{C}$

(b) $900^{\circ} \mathrm{C}$

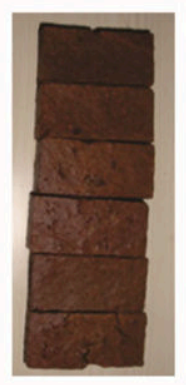

Fired bricks

Fig. 5. PMSC brick fabrication. 
Figures 6-12 summarise the mechanical characteristics of control bricks and PMSC blended

for both types of soils. It is observed, as expected, that linear shrinkage, loss on ignition, bulk density, compressive strength and modulus of elasticity increased with the peak firing temperature, while water absorption and apparent porosity decreased. The bricks made of laterite showed lower linear shrinkages since this sample contained more of the so-called filler fraction $(0.053 \mathrm{~mm}-1.2 \mathrm{~mm})$ that lowers the shrinkage, which was not the case of the alluvial soil [46]. Also, somewhat decreased water absorption and apparent porosity are observed in the case of laterite bricks. As for LOI, bulk density, compressive strength and modulus of elasticity, the laterite bricks showed higher values compared to the alluvial ones. LOI values in laterite bricks were higher because of the higher presence of $\mathrm{Fe}(\mathrm{OH})_{3}$. The change in bulk density is expected, as explained above (Table 1), as it is intensified by the firing process. Expectedly, linear shrinkage, bulk density and compressive strength are lowered with a higher percentage of PMSC, while LOI increased as observed with other organic wastes $[47,48]$. The most intensive differences between the samples, among the studied parameters, are noticed in the case of compressive strength. The compressive strength of the laterite soil (pure or mixed) samples was significantly higher than in the case of products based on the alluvial soil. Besides the better particle packing and higher bulk densities of the products, the reason is in the presence of a small percentage of montmorillonite in laterite soil, which enhanced the mechanical characteristics [46]. From the results, a blend of $10 \mathrm{wt} \%$ of PMSC was observed to satisfy engineering properties and optimal solution towards reducing fertile soil consumption in brick making. Also, the minimum compressive strength achieved with this blend of $10 \mathrm{wt} \%$ is more than $3.5 \mathrm{MPa}$, the limit specified by the Indian code of practice, satisfying the requirements of regular clay brick. 

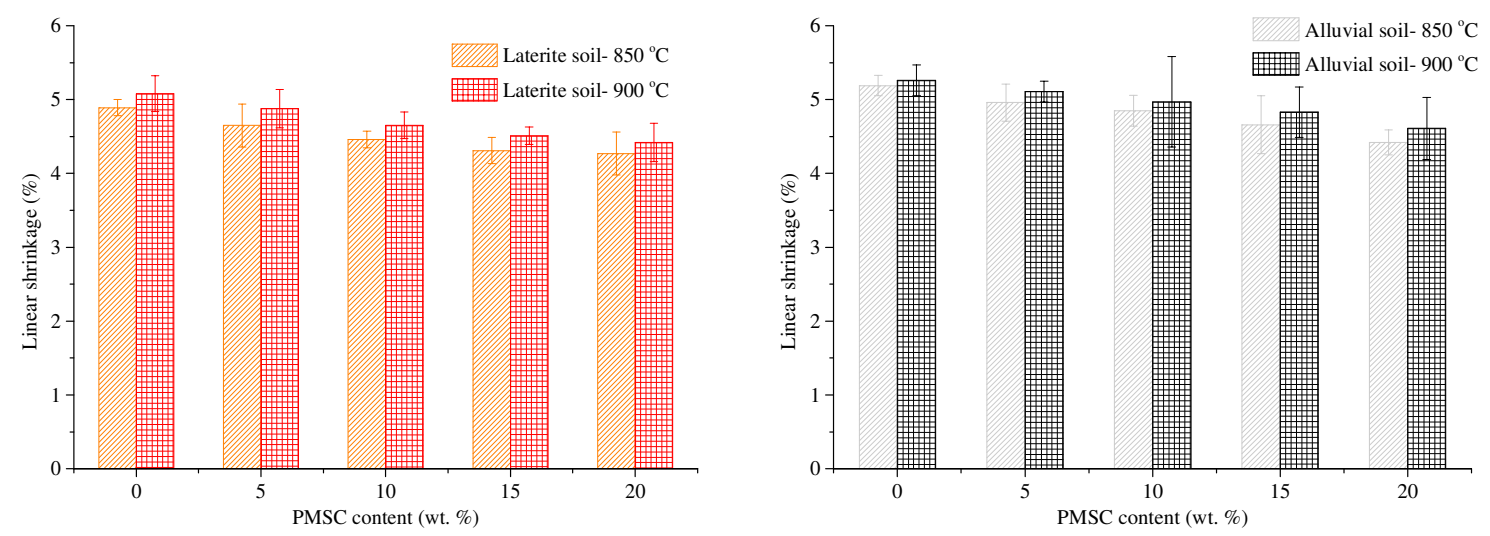

Fig. 6. Linear shrinkage of PMSC mixed bricks (a) Laterite soil blended with PMSC (b) Alluvial soil blended with PMSC - both sintered at (i) $850{ }^{\circ} \mathrm{C}$ (ii) $900{ }^{\circ} \mathrm{C}$.
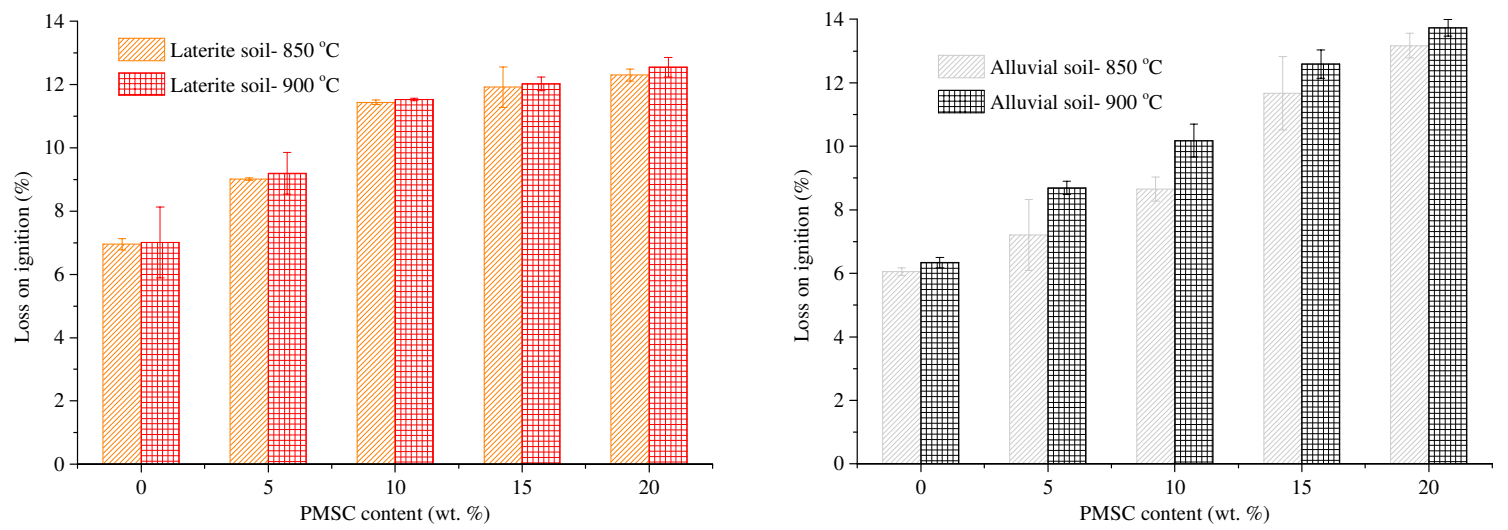

Fig. 7. Loss on ignition of PMSC mixed bricks (a) Laterite soil blended with PMSC (b) Alluvial soil blended with PMSC - both sintered at (i) $850{ }^{\circ} \mathrm{C}$ (ii) $900{ }^{\circ} \mathrm{C}$.
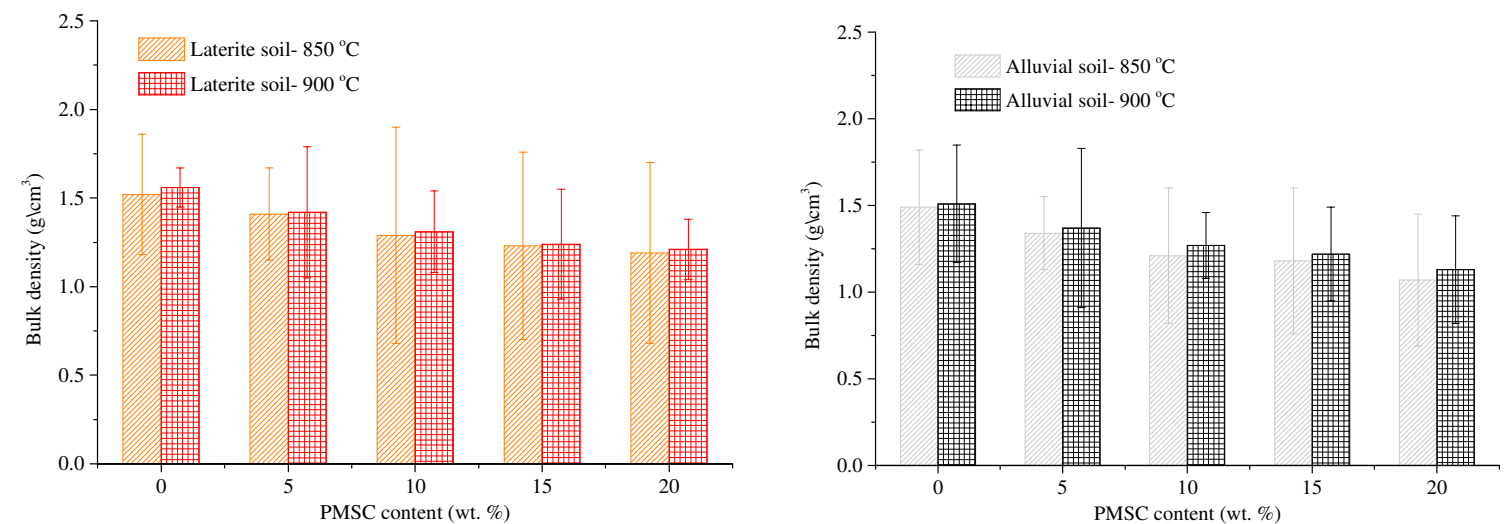

Fig. 8. Bulk density of PMSC mixed bricks (a) Laterite soil blended with PMSC (b) Alluvial soil blended with PMSC - both sintered at (i) $850{ }^{\circ} \mathrm{C}$ (ii) $900{ }^{\circ} \mathrm{C}$. 

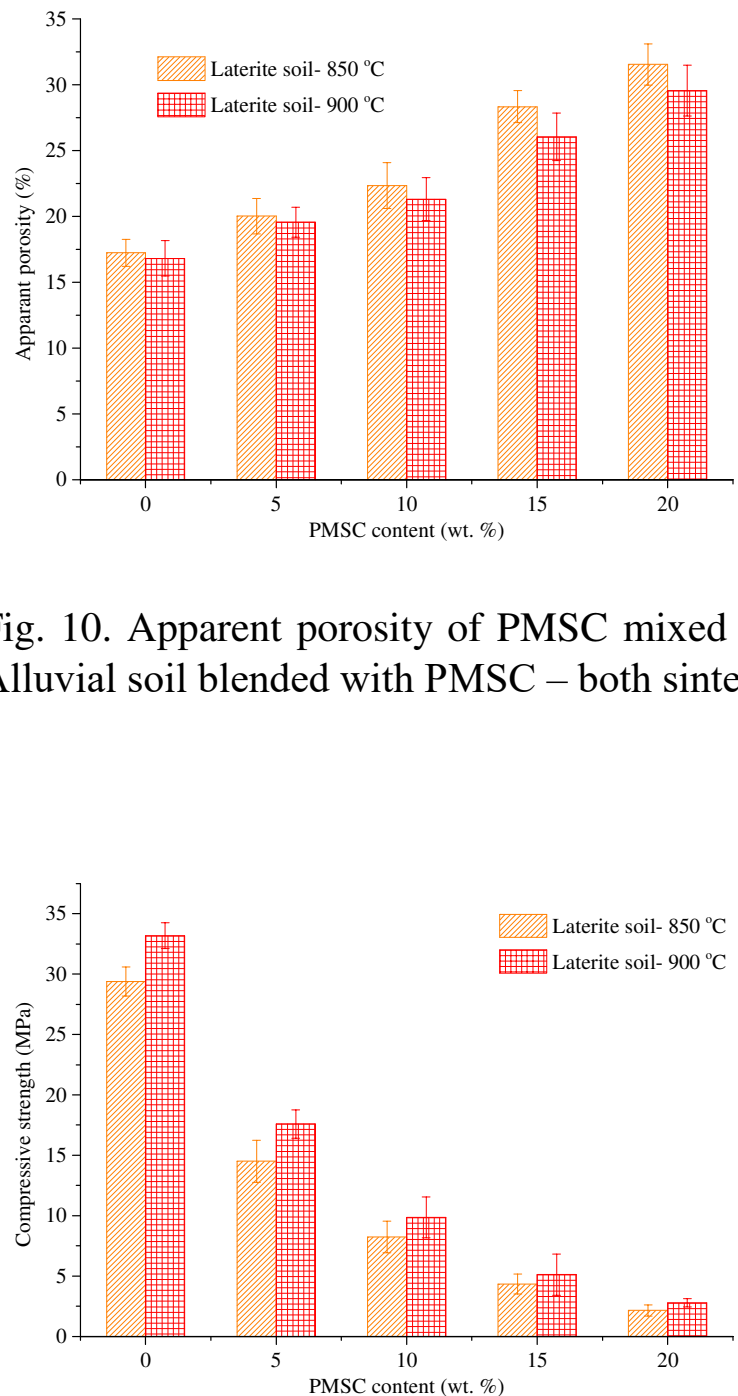

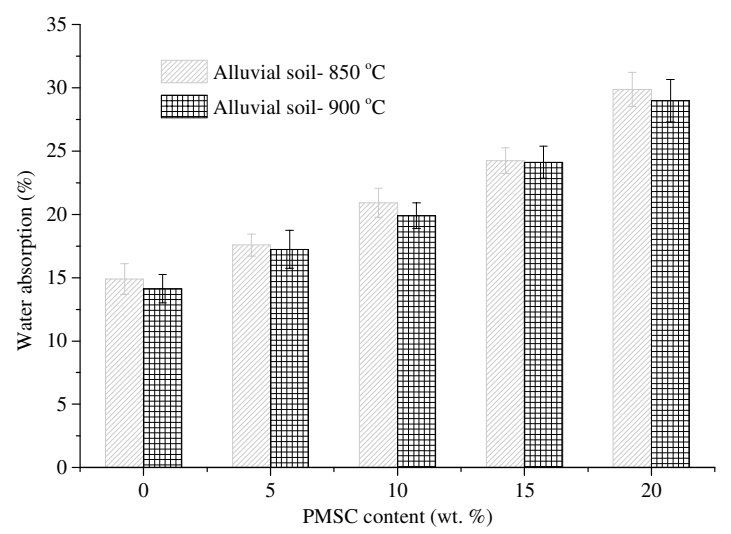

Fig. 9. Water absorption of PMSC mixed bricks (a) Laterite soil blended with PMSC (b) Alluvial soil blended with PMSC - both sintered at (i) $850{ }^{\circ} \mathrm{C}$ (ii) $900{ }^{\circ} \mathrm{C}$.

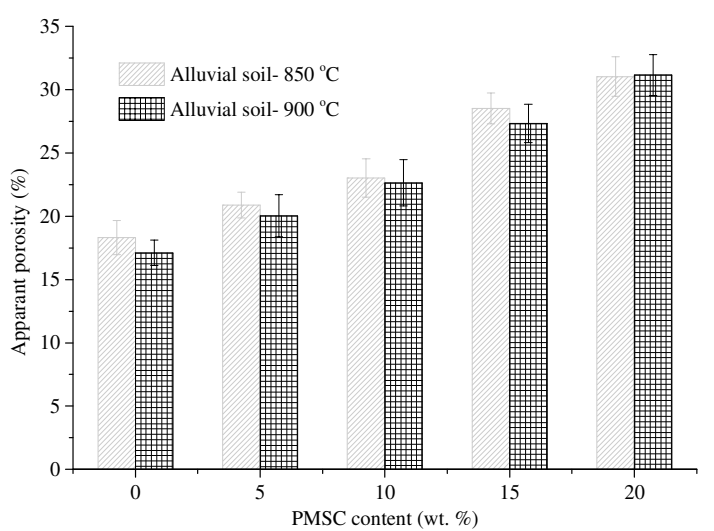

Fig. 10. Apparent porosity of PMSC mixed bricks (a) Laterite soil blended with PMSC (b) Alluvial soil blended with PMSC - both sintered at (i) $850{ }^{\circ} \mathrm{C}$ (ii) $900{ }^{\circ} \mathrm{C}$.

Fig. 11. Experimental compressive strength of PMSC mixed bricks (a) Laterite soil blended with PMSC and (b) Alluvial soil blended with PMSC - both sintered at (i) $850{ }^{\circ} \mathrm{C}$ (ii) $900{ }^{\circ} \mathrm{C}$. 
304
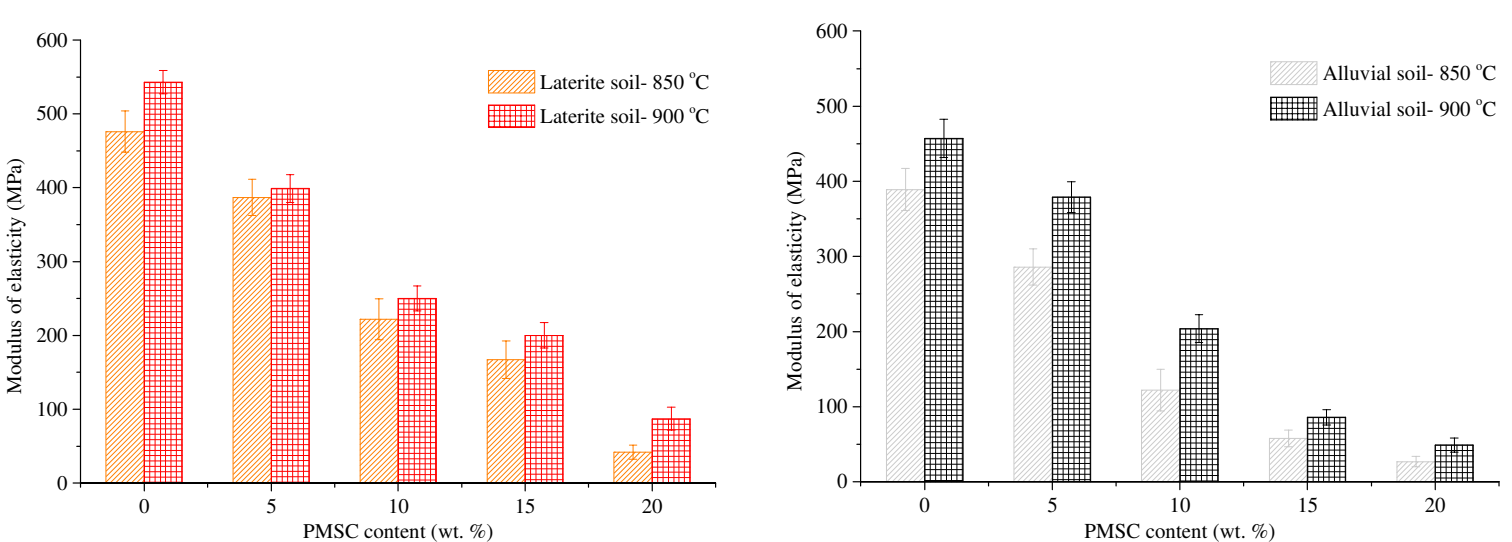

Fig. 12. Modulus of elasticity of PMSC mixed bricks (a) Laterite soil blended with PMSC and (b) Alluvial soil blended with PMSC - both sintered at (i) $850{ }^{\circ} \mathrm{C}$ (ii) $900{ }^{\circ} \mathrm{C}$.

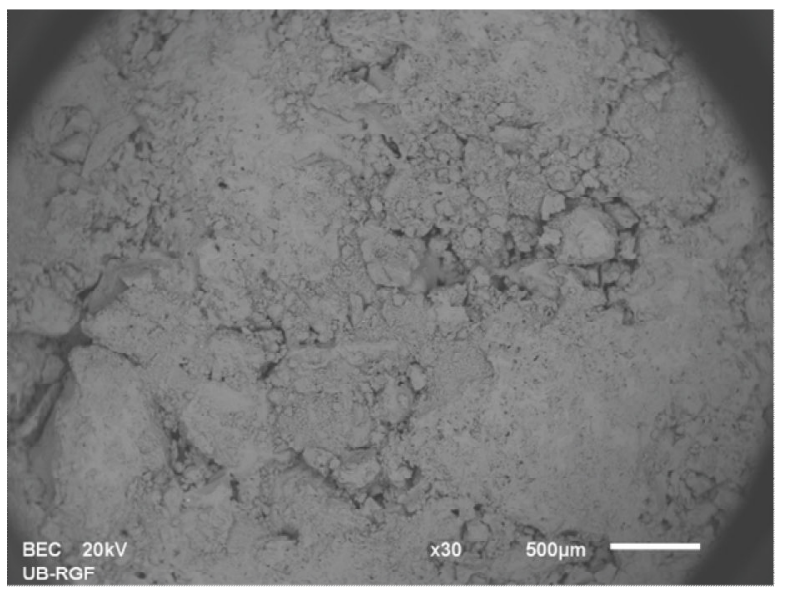

(a)

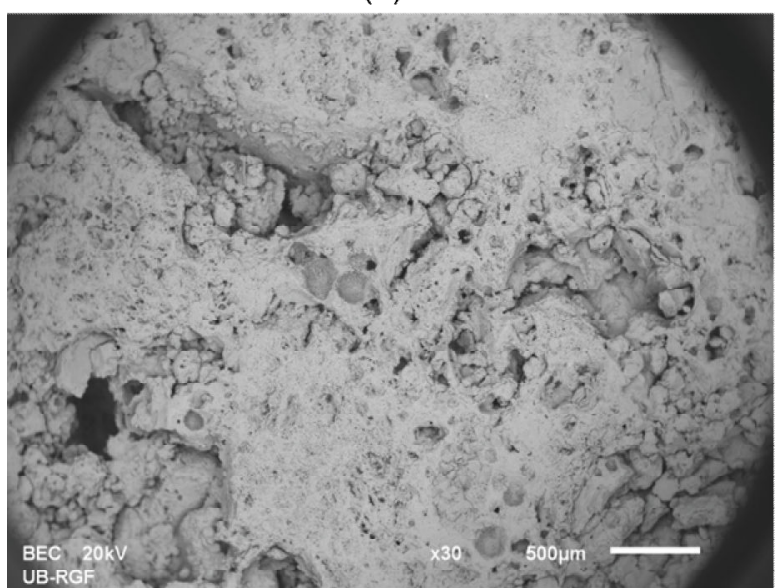

(c)

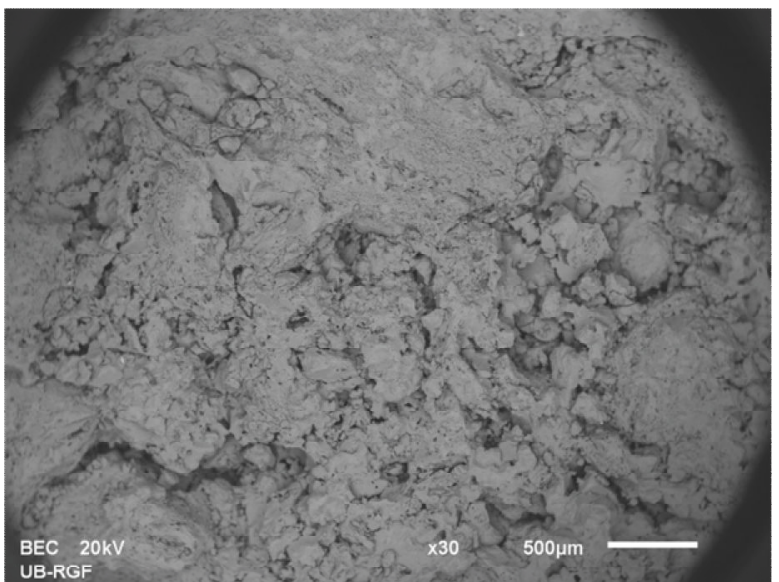

(b)

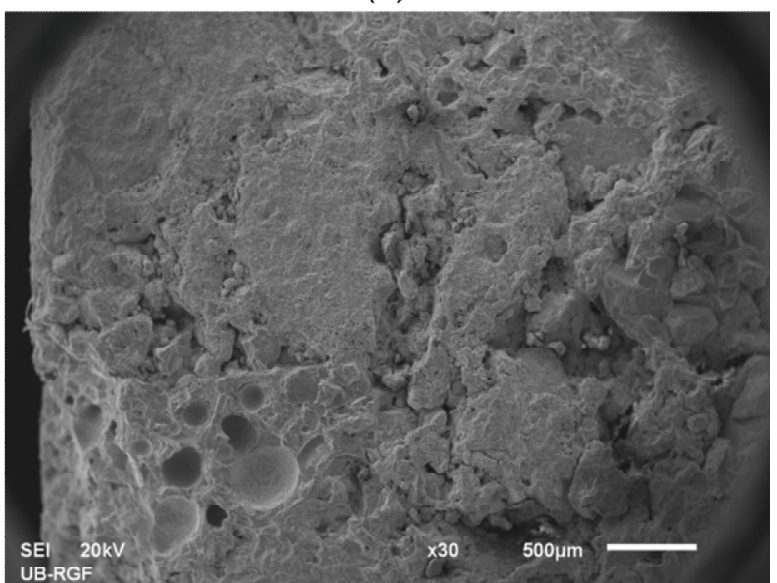

(d)

Fig. 13. SEM images of bricks: (a) Laterite soil, (b) Alluvial soil, (c) Laterite soil with $10 \mathrm{wt} \%$ of PMSC, and (d) Alluvial soil with $10 \mathrm{wt} \%$ of PMSC. All of these were fired at $900{ }^{\circ} \mathrm{C}$.

The microstructure of the bricks made from both soils is shown in Figure 13. The results of SEM analyses showed that the porosity is improved with the addition of PMSC. The results confirm higher water absorption/lower compressive strength of bricks made from both of the 
soils mixed with PMSC. Mineralogical determinations of the fired bricks were conducted using semi-quantitative analysis and presented in Table 2. Mineralogical composition and their quantitative presence were found to be almost identical for a soil type fired at a specified temperature and the occupancy of waste material did not affect it. It is noticeable that some quantity of quartz is left in all the samples after firing. Some of the $\mathrm{Fe}_{2} \mathrm{O}_{3} / \mathrm{Fe}(\mathrm{OH})_{3}$ was detected in the raw soil samples [2]. The fired samples contained hematite, which can be of hydroxide dehydroxylation and break down of the smectite minerals (montmorillonite) in laterite soil [49].

The content of hematite was raised with firing temperature according to the colour of the products. Calcium and magnesium carbonates are degraded while $\mathrm{CO}_{2}$ is released. In laterite samples, $\mathrm{Ca}$ is built into the crystal lattice of gehlenite, $\mathrm{Ca}_{2} \mathrm{Al}\left[\mathrm{AlSiO}_{7}\right]$, after firing at $850{ }^{\circ} \mathrm{C}$ and $950{ }^{\circ} \mathrm{C} . \mathrm{Mg}$ was introduced to the newly formed spinel phase after firing at a higher temperature. Aluminosilicates detected in the raw laterite soil transferred to gehlenite at 850 ${ }^{\circ} \mathrm{C}$, and then partly participated in the formation of spinel after exposure to a temperature of $900{ }^{\circ} \mathrm{C}$. Kaolinite from alluvial soil transformed to mullite after firing at $900{ }^{\circ} \mathrm{C}$.

\section{Table 2}

Semiquantitative analysis of the mineralogical composition of laterite and alluvial soil bricks fired at $850{ }^{\circ} \mathrm{C}$ and $900{ }^{\circ} \mathrm{C}$.

\begin{tabular}{llll|ll}
\hline Minerals & $\begin{array}{l}\text { ICDD } \\
\text { reference } \\
\text { card }\end{array}$ & \multicolumn{2}{c|}{ Laterite soil (\%) } & \multicolumn{2}{c}{ Alluvial soil (\%) } \\
& & $850{ }^{\circ} \mathrm{C}$ & $900{ }^{\circ} \mathrm{C}$ & $850{ }^{\circ} \mathrm{C}$ & $900{ }^{\circ} \mathrm{C}$ \\
\hline Quartz & $00-046-1045$ & 61.9 & 62.1 & 63.7 & 63.3 \\
Hematite & $00-033-0664$ & 3.0 & 2.9 & - & 2.1 \\
Gehlenite & $00-035-0755$ & 19.7 & 12.3 & - & 1.0 \\
Sillimanite & $00-038-0471$ & 15.4 & 18.6 & - & - \\
Spinel & $00-005-0672$ & - & 4.1 & - & 5.0 \\
Dolomite & $00-036-0426$ & - & - & 9.6 & - \\
Carnegieite & $00-035-0424$ & - & - & 25.9 & - \\
Rutile & $00-021-1276$ & - & - & 0.8 & 0.5 \\
Mullite & $00-002-0415$ & - & - & - & 28.1 \\
\hline
\end{tabular}


337

338

339

340

341

342

343

344

345

346

347

348

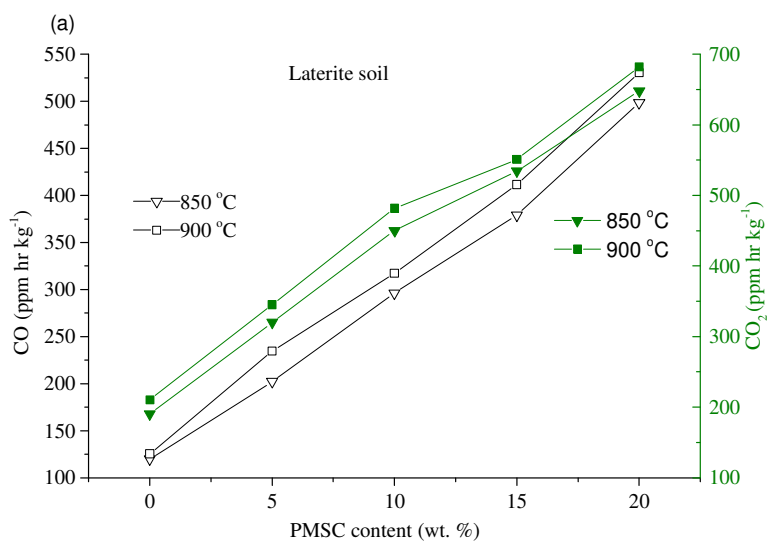

3.3. Leaching and emission tests the end of life.

Table 3 fired at $900{ }^{\circ} \mathrm{C}$.

TCLP tests were conducted on crushed samples and outcomes are provided in Table 3.

Permissible values as per EPA regulations and Indian hazardous waste management regulations are compared. It may be noticed that a $10 \mathrm{wt} . \%$ mix of the PMSC is safe to use in fired bricks.

These bricks can safely be used for construction activities and are also safe to dispose of after

TCLP test results of the laterite soil, alluvial soil bricks incorporating $10 \mathrm{wt} \%$ PMSC and

\begin{tabular}{llll}
\hline Elements & $\begin{array}{l}\text { Laterite soil } \\
(\mathbf{m g} / \mathbf{k g})\end{array}$ & $\begin{array}{l}\text { Alluvial soil } \\
(\mathbf{m g} / \mathbf{k g})\end{array}$ & $\begin{array}{l}\text { Permissible } \\
\text { limits }(\mathbf{m g} / \mathbf{k g})\end{array}$ \\
\hline $\mathrm{As}$ & 6.1 & 9.3 & 100 \\
$\mathrm{Cd}$ & 0.8 & 0.9 & 20 \\
$\mathrm{Cr}$ & 8.3 & 12.1 & 100 \\
$\mathrm{~Pb}$ & 14.3 & 18.5 & 100 \\
$\mathrm{Zn}$ & 131.4 & 234.1 & 5000 \\
$\mathrm{Mn}$ & 21.7 & 28.1 & 200 \\
$\mathrm{Ni}$ & 74.5 & 87.6 & 400 \\
$\mathrm{Co}$ & 7.3 & 11.9 & 1600 \\
\hline
\end{tabular}

349

Fig. 14. Plots showing estimated total emissions (ETEs) (ppm hr kg${ }^{-1}$ ) during the firing process.

352 There are concerns about pollution due to the firing of bricks, while countries in the Indian subcontinent rely on biomass and coal for their firing [22]. In addition to greenhouse gases, 
other gases like sulfur dioxide and oxides of nitrogen may be emitted into the atmosphere. In comparison to an actual brick kiln where the emission will be comprised of fuel and brick components, this study has the advantage of estimating emissions contributed primarily by brick soil and other additives. By measuring the area under the curve "Gas emission per unit mass versus firing time" the emission expenses for $\mathrm{CO}_{2}$ and $\mathrm{CO}$ were determined [33]. These values for (i) alluvial soil, (ii) laterite soil are presented in Fig. 14. The measurements implied lower firing temperature contributes to lower emission, which is in agreement with previous studies. These measurements help get an estimate of greenhouse gas emissions. However, a discerning determination of the emission in real-time conditions could be erroneous as the conditions in the field could vary.

\subsubsection{Benchmarking of results from previous studies}

The results obtained in this study have been benchmarked from previous studies in the literature. Engineering parameters of the fired brick such as compressive strength, water absorption, and firing shrinkage have been compared for optimum replacement ratio of the waste. The results are presented in Table 4. Values provided in brackets are a comparison of the respective property concerning control specimen (with no additive) in that study and the values have been rounded to the nearest whole number. It can be observed, all but one studies showed a loss in compressive strength. All the studies show a gain in water absorption with addition of substitute material. Firing shrinkage has been found to be losing in two studies and gaining in one study. Overall trends are linked to increased microporosity within the bricks due to the addition of the organic waste.

\section{Table 4}

Comparison of results with previous studies. Values in brackets show the comparison concerning control specimen. 


\begin{tabular}{|c|c|c|c|c|c|}
\hline Source & $\begin{array}{l}\text { Types of } \\
\text { waste and the } \\
\text { optimal firing } \\
\text { temperature }\end{array}$ & $\begin{array}{l}\% \text { of } \\
\text { optimal } \\
\text { replacement }\end{array}$ & $\begin{array}{l}\text { Compressive } \\
\text { Strength } \\
\text { (MPa) }\end{array}$ & $\begin{array}{l}\text { Water } \\
\text { Absorption } \\
(\%)\end{array}$ & $\begin{array}{l}\text { Firing } \\
\text { shrinkage } \\
(\%)\end{array}$ \\
\hline $\begin{array}{l}\text { Present } \\
\text { work }\end{array}$ & $\begin{array}{l}\text { Paper mill } \\
\text { sludge } \\
\text { compost } \\
\text { (PMSC) } \\
@ 900{ }^{\circ} \mathrm{C} \\
\text { Laterite soil }\end{array}$ & 10 & $\begin{array}{l}9.97 \\
(-69 \%)\end{array}$ & $\begin{array}{l}18.65 \\
(+41 \%)\end{array}$ & $\begin{array}{l}4.65 \\
(-8 \%)\end{array}$ \\
\hline $\begin{array}{l}\text { Goel et al., } \\
\text { [2] }\end{array}$ & $\begin{array}{l}\text { Paper mill } \\
\text { sludge (PMS) } \\
@ 900{ }^{\circ} \mathrm{C} \\
\text { Laterite soil }\end{array}$ & 10 & $\begin{array}{l}9.85 \\
(-70 \%)\end{array}$ & $\begin{array}{l}18.83 \% \\
(+41 \%)\end{array}$ & $\begin{array}{l}4.61 \\
(-9 \%)\end{array}$ \\
\hline $\begin{array}{l}\text { Singh et } \\
\text { al., [50] }\end{array}$ & $\begin{array}{ll}\text { Deinking } & \\
\text { Paper } & \text { mill } \\
\text { sludge } & \\
@, 950{ }^{\circ} \mathrm{C} & \\
\end{array}$ & 15 & $\begin{array}{l}5.0 \\
(-54 \%)\end{array}$ & $\begin{array}{l}28.57 \\
(+52 \%)\end{array}$ & $\begin{array}{l}3.06 \\
(+8 \%)\end{array}$ \\
\hline $\begin{array}{l}\text { Arsenović } \\
\text { et al., [51] }\end{array}$ & $\begin{array}{l}\text { Sunflower } \\
\text { husks, } \\
\text { @ } 850{ }^{\circ} \mathrm{C}\end{array}$ & 5 & $\begin{array}{l}20.15 \\
(-52 \%)\end{array}$ & $\begin{array}{l}10.48 \\
(+14 \%)\end{array}$ & - \\
\hline $\begin{array}{l}\text { Arsenović } \\
\text { et al., [52] }\end{array}$ & $\begin{array}{l}\text { Wooden } \\
\text { sawdust, } \\
\text { @ } 850^{\circ} \mathrm{C}\end{array}$ & 2.5 & $\begin{array}{l}20.97 \\
(-50 \%)\end{array}$ & $\begin{array}{l}13.9 \\
(+33 \%)\end{array}$ & - \\
\hline $\begin{array}{l}\text { Demir, } \\
\text { [53] }\end{array}$ & $\begin{array}{l}\text { Processed } \\
\text { Waste Tea } \\
\text { (a) } 900{ }^{\circ} \mathrm{C}\end{array}$ & 5.0 & $\begin{array}{l}22.7 \\
(+46 \%)\end{array}$ & $\begin{array}{l}27.30 \\
(+52 \%)\end{array}$ & - \\
\hline
\end{tabular}

\section{Conclusions}

bricks which is also necessary to meet the obligation towards circular economy. In continuation of this effort, the present study explores the use of paper mill sludge compost (PMSC) as an additive in making fired bricks and proposes guidelines representative of kiln conditions on what parameters should be used to obtain the desired results. This work shows that PMSC is suitable for utilization in fired bricks making. While establishing a strong linkage to the 
brickmaker on the use of PMSC in brick making. These discussions lead towards the following reasoning supported by experimental evidence:

1. The presence of fluxing agents in PMSC as confirmed by XRF is beneficial and helpful in reducing the used energy by lowering firing temperatures which are also critical towards comprehensive firing and minimizing any defects. It was also noticed that cellulose fibers acted as reinforcement and stabilize the magnitude of linear shrinkage in unfired bricks. Laterite soil samples showed a repeatedly higher compressive strength of the brick samples than the alluvial soil samples because of the wider particle size distribution and the presence of a low quantity of montmorillonite.

2. From the results, a blend of $10 \mathrm{wt} \%$ of PMSC was observed to satisfy engineering properties and optimal solution towards reducing fertile soil consumption in brick making. Also, the minimum compressive strength achieved with this blend of $10 \mathrm{wt} \%$ is more than 3.5 MPa, the limit specified by the Indian code of practice, satisfying the requirements of regular clay brick. A higher firing temperature $\left(900{ }^{\circ} \mathrm{C}\right)$ is gainful towards increasing the durability of bricks.

3. The commingled $10 \mathrm{wt} \%$ PMSC helped lightening of bricks by $14-16 \%$ cutback in bulk density. This proposition is a pathway favoring cost-effective construction by the reduction in haulage cost and labor efforts as well as uplifting the state of recyclability while addressing the issue of waste management and promoting the concept of the circular economy. Also due to its calorific value, it reduces the expense of energy during firing.

4. Greenhouse gases $\left(\mathrm{CO}\right.$ and $\left.\mathrm{CO}_{2}\right)$ emission measurements help get the estimate of these values however discerning emission values in real-time conditions could be erroneous as the conditions in the field could vary. 


\section{Acknowledgments}

416

417

Gaurav greatly acknowledge the financial support provided by the Royal Academy of Engineering via Grants No. IAPP18-19\295 and EXPP2021\1\277, and EU Cost Action (CA15102, CA18220, CA18224, CA17133 and CA17136). We also acknowledge financial support from the European Regional Development Funds (ERDF) sponsored A2i project at LSBU that has catalyzed several industrial partnerships. Milica V. Vasić acknowledges the financial support received from the Ministry of Education, Science and Technological Development of the Republic of Serbia (Contract No. 451-03-68/2020-14/200012). Nirmal acknowledges the Newton Fellowship award from the Royal Society (NIF\R1\191571).

\section{References}

[1] G. Goel, A.S. Kalamdhad, Degraded municipal solid waste as partial substitute for manufacturing fired bricks, Construction and Building Materials 155 (2017) 259-266. [2] G. Goel, A.S. Kalamdhad, An investigation on use of paper mill sludge in brick manufacturing, Construction and Building Materials 148 (2017) 334-343.

[3] P. Bajpai, Management of Pulp and Paper Mill Waste, Springer International Publishing Switzerland 2015.

[4] S. Seifi, N. Sebaibi, D. Levacher, M. Boutouil, Mechanical performance of a dry mortar without cement, based on paper fly ash and blast furnace slag, Journal of Building Engineering 22 (2019) 113-121.

[5] S. Cordiner, G. De Simone, V. Mulone, Experimental-numerical design of a biomass bubbling fluidized bed gasifier for paper sludge energy recovery, Applied Energy 97(Supplement C) (2012) 532-542.

[6] A. Demirbas, Progress and recent trends in biofuels, Progress in Energy and Combustion Science 33(1) (2007) 1-18.

[7] C. Veluchamy, A.S. Kalamdhad, Enhancement of hydrolysis of lignocellulose waste pulp and paper mill sludge through different heating processes on thermal pretreatment, J Clean Prod 168 (2017) 219-226.

[8] Y.H. Yu, S.D. Kim, J.M. Lee, K.H. Lee, Kinetic studies of dehydration, pyrolysis and combustion of paper sludge, Energy 27(5) (2002) 457-469.

[9] H.S. Wong, R. Barakat, A. Alhilali, M. Saleh, C.R. Cheeseman, Hydrophobic concrete using waste paper sludge ash, Cement and Concrete Research 70(Supplement C) (2015) 9-20. [10] S. Migneault, A. Koubaa, H. Nadji, B. Riedl, S.T. Zhang, J. Deng, Medium-density fiberboard produced using pulp and paper sludge from different pulping processes, Wood and Fiber Science 42(3) (2010) 292-303. 
[11] S. Kim, H.-J. Kim, J.C. Park, Application of recycled paper sludge and biomass materials in manufacture of green composite pallet, Resources, Conservation and Recycling 53(12) (2009) 674-679.

[12] M. Sutcu, S. Akkurt, Utilization of recycled paper processing residues and clay of different sources for the production of porous anorthite ceramics, Journal of the European Ceramic Society 30(8) (2010) 1785-1793.

[13] C.M.F. Vieira, R.M. Pinheiro, R.J.S. Rodriguez, V.S. Candido, S.N. Monteiro, Clay bricks added with effluent sludge from paper industry: Technical, economical and environmental benefits, Applied Clay Science (2016).

[14] J.A. Cusido, L.V. Cremades, C. Soriano, M. Devant, Incorporation of paper sludge in clay brick formulation: Ten years of industrial experience, Appl Clay Sci 108 (2015) 191198.

[15] J. Hazarika, U. Ghosh, A.S. Kalamdhad, M. Khwairakpam, J. Singh, Transformation of elemental toxic metals into immobile fractions in paper mill sludge through rotary drum composting, Ecol Eng 101(Supplement C) (2017) 185-192.

[16] P. Sonowal, M. Khwairakpam, A.S. Kalamdhad, Stability Analysis of Dewatered Sludge of Pulp and Paper Mill During Vermicomposting, Waste Biomass Valori 5(1) (2014) 19-26. [17] A. Lakhouit, A.R. Cabral, H. Cabana, Two Novel Biofilters to Remove Volatile Organic Compounds Emitted by Landfill Sites, Water, Air, \& Soil Pollution 227(4) (2016) 113. [18] A. Khoshand, M. Fall, Geotechnical Characterization of Compost Based Biocover Materials, Geotechnical and Geological Engineering 32(2) (2014) 489-503.

[19] C.G. Chiochetta, S. Cotelle, J.-F. Masfaraud, H. Toumi, G. Quaranta, F. Adani, C.M. Radetski, Use of agro-industrial organic sludge amendment to remediate degraded soil: chemical and eco(geno)toxicological differences between fresh and stabilized sludge and establishment of application rates, Environmental Science and Pollution Research 23(4) (2016) 3018-3025.

[20] S. Torii, S. Watanabe, Combustion Characteristics of Combustion Chamber Using Compost as a Fuel, Energy Procedia 61 (2014) 9-12.

[21] S.N. Monteiro, C.M.F. Vieira, On the production of fired clay bricks from waste materials: A critical update, Construction and Building Materials 68 (2014) 599-610. [22] C. Bhushan, D.D. Basu, N.K. Yadav, R. Kumar, National Brick Mission-A scoping paper, Roadmap for Brick Kiln Sector: Challenges and Opportunities, Centre for Science and Environment, New Delhi, 2016. [23] K. Hamer, V. Karius, Brick production with dredged harbour sediments. An industrialscale experiment, Waste Management 22(5) (2002) 521-530.

[24] R.V. Silva, J. de Brito, C.Q. Lye, R.K. Dhir, The role of glass waste in the production of ceramic-based products and other applications: A review, J Clean Prod 167 (2017) 346-364. [25] S.M.S. Kazmi, M.J. Munir, Y.-F. Wu, A. Hanif, I. Patnaikuni, Thermal performance evaluation of eco-friendly bricks incorporating waste glass sludge, Journal of Cleaner Production 172 (2018) 1867-1880.

[26] M.V. Madurwar, R.V. Ralegaonkar, S.A. Mandavgane, Application of agro-waste for sustainable construction materials: A review, Constr Build Mater 38 (2013) 872-878.

[27] S.M.S. Kazmi, M.J. Munir, I. Patnaikuni, Y.-F. Wu, U. Fawad, Thermal performance enhancement of eco-friendly bricks incorporating agro-wastes, Energy and Buildings 158(Supplement C) (2018) 1117-1129.

[28] A. Ukwatta, A. Mohajerani, N. Eshtiaghi, S. Setunge, Variation in physical and mechanical properties of fired-clay bricks incorporating ETP biosolids, Journal of Cleaner Production 119 (2016) 76-85. 
[29] M.J. Munir, S.M.S. Kazmi, Y.-F. Wu, A. Hanif, M.U.A. Khan, Thermally efficient fired clay bricks incorporating waste marble sludge: An industrial-scale study, Journal of Cleaner Production 174(Supplement C) (2018) 1122-1135.

[30] J. Singh, A.S. Kalamdhad, Assessment of bioavailability and leachability of heavy metals during rotary drum composting of green waste (Water hyacinth), Ecol Eng 52 (2013) 59-69.

[31] BIS:2117-, Guide for manufacture of hand made common burnt clay buliding bricks (3rd revision), in: B.o.I.S. (BIS) (Ed.) Bureau of Indian Standards (BIS), New Delhi, India, 1991. [32] BIS:11650-, Guide for manufacture of common burnt clay building bricks by semimechanized process (I revision), in: B.o.I.S. (BIS) (Ed.) Bureau of Indian Standards (BIS), New Delhi, India, 1991.

[33] G. Goel, A.S. Kalamdhad, A practical proposal for utilisation of water hyacinth: Recycling in fired bricks, Journal of Cleaner Production 190 (2018) 261-271. [34] J. Singh, A.S. Kalamdhad, Effects of lime on bioavailability and leachability of heavy metals during agitated pile composting of water hyacinth, Bioresource Technol 138 (2013) 148-155.

[35] BIS:1077-, Common Burnt Clay Building Bricks -Specification (5th revision), in: B.o.I.S. (BIS) (Ed.) Bureau of Indian Standards (BIS), New Delhi, India, 1992.

[36] ASTM:C67-14, Standard Test Methods for Sampling and Testing Brick and Structural Clay Tile, in: ASTM (Ed.) Pennsylvania, United States.

[37] BIS:3495-, Methods of Tests of Burnt Clay Building Bricks, in: B.o.I.S. (BIS) (Ed.) Bureau of Indian Standards (BIS), New Delhi, India, 1992.

[38] ASTM:D695-15, Standard Test Method for Compressive Properties of Rigid Plastics, in: ASTM (Ed.) Pennsylvania, United States.

[39] T.K. Dan, B.K. Sarkar, Properties of Bricks from Lateritic Waste, Ceram Int 17(6) (1991) 351-357.

[40] M. Loutou, Y. Taha, M. Benzaazoua, Y. Daafi, R. Hakkou, Valorization of clay byproduct from moroccan phosphate mines for the production of fired bricks, Journal of Cleaner Production 229 (2019) 169-179.

[41] F. Cardarelli, Materials Handbook: A concise desktop reference, Springer-Verlag London, London, 2008.

[42] H.G.F. Winkler, Bedeutung der Korngroßenverteilung und des Mineralbestandes von Tonen für die Herstellung grobkeramischer Erzeugnisse, Berichte der Deutschen Keramischen Gesellschaft 31 (1954) 337-343.

[43] M.L. Diko, G.E. Ekosse, S.N. Ayonghe, E.B. Ntasin, Physical characterization of clayey materials from tertiary volcanic cones in Limbe (Cameroon) for ceramic applications, Applied Clay Science 51(3) (2011) 380-384.

[44] H. Winkler, Bedeutung der Korngrößenverteilung und des Mineralbestandes von Tonen für die Herstellung grobkeramischer Erzeugnisse, Berichte der Deutschen Keramischen Gesellschaft 31(10) (1954) 337-343.

[45] A.V. Kornilov, Reasons for the different effects of calcareous clays on strength properties of ceramics, Glass and Ceramics 62(11) (2005) 391-393.

[46] M. Arsenović, Optimization and prediction of the quality of materials, process and final properties of heavy clay products by mathematical modeling of the characteristic parameters, Faculty of technology and metallurgy, University of Belgrade, Serbia, 2013.

[47] A. Ukwatta, A. Mohajerani, Effect of Organic Content in Biosolids on the Properties of Fired-Clay Bricks Incorporated with Biosolids, Journal of Materials in Civil Engineering 29(7) (2017) 04017047.

[48] A. Yaras, Combined effects of paper mill sludge and carbonation sludge on characteristics of fired clay bricks, Construction and Building Materials 249 (2020) 118722. 
549 [49] M. Arsenovic, Z. Radojevic, S. Stankovic, Removal of toxic metals from industrial 550 sludge by fixing in brick structure, Construction and Building Materials 37 (2012) 7-14.

551 [50] S.K. Singh, S. Kulkarni, V. Kumar, P. Vashistha, Sustainable utilization of deinking 552 paper mill sludge for the manufacture of building bricks, Journal of Cleaner Production 204 553 (2018) 321-333.

554 [51] M. Arsenović, Z. Radojević, Ž. Jakšić, L. Pezo, Mathematical approach to application of 555 industrial wastes in clay brick production - Part I: Testing and analysis, Ceramics

556 International 41(3, Part B) (2015) 4890-4898.

557 [52] M. Arsenović, Z. Radojević, Ž. Jakšić, L. Pezo, Mathematical approach to application of 558 industrial wastes in clay brick production-Part II: Optimization, Ceramics International 559 41(3, Part B) (2015) 4899-4905.

560 [53] I. Demir, An investigation on the production of construction brick with processed waste 561 tea, Building and Environment 41(9) (2006) 1274-1278. 
$2021-01-30$

Potential pathway for recycling of the paper mill sludge compost for brick making

\author{
Goel, Gaurav
}

Elsevier

Goel G, Vasic MV, Kumar Katiyar N, et al., (2021) Potential pathway for recycling of the paper mill sludge compost for brick making, Construction and Building Materials, Volume 278, April 2020, Article number 122384

https://doi.org/10.1016/j.conbuildmat.2021.122384

Downloaded from Cranfield Library Services E-Repository 